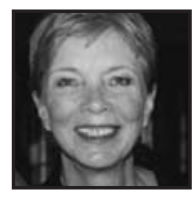

\title{
Poetry as Breath: Teaching Student Teachers to Breathe-Out Poetry
}

\author{
Lesley Pasquin, McGill University
}

\section{ABSTRACT}

Poetry is a form of creative expression that exists to share a truth, an insight, or a feeling that enriches our humanity. "Teaching" poetry requires us to be readers and writers of poetry ourselves. It requires that we are saying, "Poetry matters." I work with second-year student teachers in my Language Arts Methods class at McGill University to develop a passion for the poetic; to learn what Muriel Rukeyser refers to as breathing-in experience and breathing-out poetry. Using my own writing process and immersing my students in the genre, they begin to construct the complex understanding of why poetry matters and why that understanding is crucial to teaching it.

Breathe-in experience,

Breathe-out poetry.

- Muriel Rukeyser

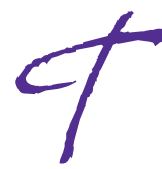

here is no "how to" in teaching poetry. It is a not a transmission of knowledge, it is an awakening of passion. What is key is the understanding that poetry matters. In order to create that true understanding, we must first be able to articulate why it matters for us and why it will matter for the children we will teach. In my Language Arts Methods course in the Faculty of Education at McGill University, poetry as both an expression of self and a genre to be taught are on the syllabus. I arrive one afternoon for class laden with heavy bags of books. Poetry books. Anthologies of poems for children that somehow my twenty-something 
students had never seen in their elementary or high school years. I ask them about their memories of poetry in school. Some remember rhythm and rhyme. Most remember picking the poem apart line by line, understanding simile, metaphor, personification, iambic pentameter. Some remember the terms alliteration and onomatopoeia-such a word could be a poem itself. Even today, on the cutting edge of one of the finest curriculums in the world, the heavy slogging through a poem is all they seem to know. Few remember that poetry mattered in any personal way. Perhaps one or two still read it. Some want nothing to do with it. Muriel Rukeyser admonishes us. "The fear of poetry," she says, "is an indication that we are cut off from our own reality" (1996, p. 30).

The student teachers devour the books I bring. The assignment is to read to each other in groups and after the initial uncertainty of the simplicity of this task, the room is a hubbub. Poetry in action, catching the reader sometimes off guard with the message or the language. Imagine these university students coming across Yeats for the first time in a book for children.

\section{There was a man whom Sorrow named his friend \\ And he, of his high comrade Sorrow dreaming, \\ Went walking with slow steps along the gleaming}

The Sad Shepherd (Allison, 2002, p. 8)

What did I mean that they were not to analyze Yeats? After all, they had struggled with the meaning of poetry all through their high school years and now a poem presented itself as a problem to be solved, in a fashion that must please the teacher and the examiner. Just read, I say. Just listen to the beauty of the language, let it roll over you. This is one of their favourite classes, this freeing up of meaning. The group must pick one and read to the entire class. Many say this is the first time they have read a poem out loud to a group. They tend to choose poems that are lighthearted to avoid the work that must be done to get at meaning. How will you be able to do this with children I ask? If we are to teach this genre, we must live it.

However superficial this introduction to poetry seems, it is a way of first getting poetry into the hands of those who will teach it. The student teachers leave with a list of poems and poets they could use in their own classrooms. Now, the key to understanding what matters is to sit with the work, reading and rereading to create a deeper connection between reader and text. A poem, by its very definition, a 
verbal composition designed to convey experiences, ideas, or emotions in a vivid and imaginative way, characterized by the use of language chosen for its sound and suggestive power, calls us to the detail of the words, so carefully chosen over prose that they create a kind of order from chaos, a way of looking that will cause the reader to rethink the world or to identify with something within calling for meaning.

We move from the surface to the undertow. In groups and then individually, the students respond to poems I have brought. Depending on the year and my own reading close to the course, I may be reading them poems by May Sarton, Mary Oliver, Lorna Crozier, Gwendolyn McEwen, Leonard Cohen, Rilke, Rumi, Anne Michaels, Anne Carson or local Montreal poets they did not know existed, including me. The list is open to all possibilities, as are their collective responses to the poems. They are startled back into adulthood. Take a chance, I tell them. There are no wrong answers. We want to move from immersion in the genre to specific responses, to another reason why poetry matters: it calls the reader to think, to be involved, to connect, to understand for ourselves what Mary Oliver means when she asks the reader,

Tell me, what is it you plan to do

with your one wild and precious life?

(Oliver, 1992, p. 94)

In The Life of Poetry, her ground-breaking work on the subject, Muriel Rukeyser declares, "I wish to say that we will not be saved by poetry. But poetry is the type of creation in which we may live and which will save us" (p. 213). I share student responses from a grade six class, on how poetry may have been both necessary and helpful.

The thing I liked most about this year was poetry. I liked how we explored all sorts of different forms of poetry. The thing I was disappointed with, in poetry, was that we didn't get into deeper poetry. What I mean by deeper poetry is more personal. There are already kids on our grade who need to get things out, but don't no [sic] how, so give them the choice.

Shannon (pseudonym), age 12

At the age of twelve, Shannon has already understood that poetry matters. She is in fact breathing in poetry, and breathing out experience. She uses poems to "get things out," and wants others to have that experience, that choice. She wants to know, in the words of Deena Metzger, 
how very dark the woods are, because we suspect we will have to face how very dark the woods are ... how dangerous and how miraculous are strangers, and how reliable or tricky the kingdom of nature ... how more than anything we want to be awake. (1992, p. 136)

I shall start with my first opinion. The guy is mentally sick. I got this from, "They shall miss the whisper that runs any day in your mind." But then we finished reading it. The guy only wants to know who he is. He wants to know the meaning of life. He wants to know why he was put on earth. It's like God made him underprivileged and maybe a little too civilized. His mind wants him to give up hope but his heart won't let him. I got this from. "Maybe I'm a king." We're all a king in one way or another.

Brian (pseudonym), age 12

What is Brian telling us about his interaction with William Stafford's A Story That Could Be True? He is using what he knows to understand at a deep level that we can all claim who we are, that hope is tangible and that the heart is what drives us, important concepts for a twelve year old. He is not a passive reader, but rather one who is "concentrating his attention on the world he has evoked" (Rosenblatt, 1978, p. 86). Breathe-in poetry, breathe-out experience. This is what Brian has done. His reflection is what James Britton refers to as:

virtual re-enactment ...poetic discourse (which) presents contemplative reflections upon experience ... these reflections are not analytical in manner rather they constitute reflection by re-enactment-or, in the case of imagined experiences or other people's experiences, by a kind of rehearsal that might perhaps be called virtual re-enactment. (1993, p. 126)

As teachers, and poets, we must listen to voices like Shannon's and we must understand that the Brians are capable of deep response.

Poetry is a form of creative expression that exists to share a truth, an insight, or a feeling that enriches our humanity. It is part of an emotional ecosystem. We know the poem matters when it creates what Louise Rosenblatt calls a live circuit, when it, "comes into being in the live circuit set up between the reader and the text" (p. 14). "No one," says Rosenblatt,"can read a poem for you" (p. 86). 
If no one can read a poem for you, then certainly no one can write a poem for you. Naomi Shihab Nye puts it this way; “You can not order a poem like you order a taco." (1994, p. 70) We ask children in classrooms to write poems. Why not do it ourselves to understand what it requires. Young children will write poems the way they paint or draw - with confidence that they have something to express. My class is not so sure, so we begin by picking a line as a prompt. For me, the line someone has chosen at random, "I have to go to bed by day," from Robert Louis Stevenson produced:

\author{
I have to go to bed by day \\ for I am weary of the night. \\ By day, the bed is cool, \\ the sheets fine under \\ the turning of the fan, \\ the sun translucent. \\ I will be a mole \\ burrow under the covers, \\ go underground where \\ in my day blindness \\ I can dream the night dreams \\ the eclipse of the moon, the buildings \\ of the city lit with neon \\ my own name flashing somewhere \\ calling, come out into the night.
}

(Pasquin, 2008) ${ }^{1}$

I am breathing in experience, breathing out poetry.

Georgia Heard gives us another excellent starting exercise in her book Writing Towards Home. She suggests the use of Nye's Valentine for Earnest Mann as a writing prompt (1995, p. 10). The poem may be waiting to be written. Maybe, as in this poem, it hides in the eyes of skunks. Certainly it comes from what we have experienced, what we have breathed in of life. We write together, the students and I. Where do our poems hide? On one such class day, my poem had been hiding under the verandah, as earlier in the week I had discovered the fox. In class I wrote this draft. The students wrote their own drafts and were amazed by what memories and experiences this question had conjured. Slowly, in small groups, they shared their fledgling poems, coming to the realization that by pushing a boundary of what mattered to 
them, they could write a poem. They come to know the meaning of, "breathe-in experience, breathe-out poetry."

\title{
Fox
}

\begin{abstract}
A fox lay dead under the porch all winter, unnoticed except for the dog's unavailed keening and rooting one December morning. The body was perfect come spring. I have taken old cats to be put down, helped them breathe their last, but I was not prepared for this; the sweet scent of decay, that some wild being had come to die. We cut the floorboards stepping across the curled body as though it were a revered ancestor carefully lifted from the dust.

There was no saving him, no final rites or coins on the eyes, open and unseeing, a death not expected that day.
\end{abstract}

(Pasquin, 2008) $)^{2}$

"What prompts us to write?" I ask them. We write about what matters. We create around what matters. We write the stories that need to be told. We read the stories that need to be heard.

Everywhere we are all made to "desensitize" twenty-first-century-style. If children aren't playing with toads or talking with each other or sitting in a park observing, can you interest them in poetry? Can we interest adults? "Are we to teach this?" asks Rukeyser. "All we can show to people is themselves, show them what passion they possess and we will have come to poetry (p. 40).

And so we come full circle; reading, responding, writing; a better understanding of the process, of the imperative to have a classroom filled with poems and the freedom to love the words in an unrestrained manner, to write the words in an unrestrained manner."Poetry matters because it serves up the substance of our lives," 
says Jay Parini in his book of the same title. "Its adequacy to experience is profound and lasting." (2008, p. 181).

What is the story we are each called to tell and in the telling may serve up the substance of our lives? Encouraging student teachers to tell their stories through poetry, to share in moments when they will understand that it matters to know, "how very dark the woods are" (Metzger, 1992, p. 136), will make them far better teachers of the genre that needs to be taught, no, lived with passion.

\section{Succour}

Imagine your heart is so petrified, it simply drops from your chest onto the sidewalk for someone else to find.

Do you wander heartless?

And the woman who claims it?

Will she search for you, easy to find with your gaping wound, or will she keep the heart, wondering about the story that needs to be told, how someone, somewhere is fading, blood no longer carrying breath, bog bones brittle.

The story that needs to be told is that even a butterscotch lollipop can give you comfort; that duck decoys are to be avoided, but not small green frogs or the bracken at the edge of the rock; that walking barefoot after a storm to pick armfuls of downed peonies is an act of reverence; that naming things makes them so and a life can be built from small scraps of paper on which 
you have written the meaning

of everything.

Two rocks on the shore barely touch

but if one were moved, the entire scene would change. Water knows

this. Wind knows this.

Stand with your palm upturned

to catch the rain.

Learn to rely on the kindness of bears.

(Pasquin, 2004) $)^{3}$

In poetry readings I have done, I wait, as the poet, for the in breath of the audience at the end of the final line. It is then I know that they have "breathed-in" my poem with their own meaning and that they may take a new perspective or ideology from a cold winter night in a small café to help make sense of their world.

\section{Notes}

1. Reprinted with the author's permission.

2. Reprinted with the author's permission.

3. Reprinted with the author's permission. Originally published in carte blanche, issue 6. 


\section{References}

Allison, J. (2002). Poetry for young people: William Butler Yeats. New York: Sterling.

Britton, J. (1993). Literature in its place. Portsmouth, $\mathrm{NH}$ : Heinemann.

Heard, G. (1995). Writing towards home. Portsmouth, $\mathrm{NH}$ : Heinemann.

Metzger, D. (1992). Writing for your life: A guide and companion to the inner worlds. New York: Harper Collins.

Nye, N.S. (1994). Red suitcase. New York: BOA Editions.
Oliver, M. (1992). New and selected poems. Boston: Beacon Press.

Parini, J. (2008). Why poetry matters. New Haven: Yale University Press.

Rosenblatt, L. (1978). The reader, the text, the poem: The transactional theory of the literary work. Carbondale: Southern Illinois University Press.

Rukeyser, M. (1996). The life of poetry. Ashfield: First Paris Editions Press.

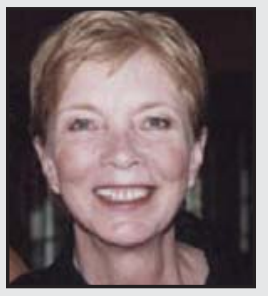

Lesley Pasquin is a Montreal writer, poet and educator. She has been a classroom teacher, a resource teacher, an Educational Consultant and an Elementary School Principal. She currently teaches in the Department of Integrated Studies in the Faculty of Education at McGill University. She has a strong belief in the power of the arts in the classroom. Her work has been published in Arc Magazine, Room Magazine, carte-blanche and Montreal Serai.

She is a member of the Quebec Writers' Federation, the League of Canadian Poets, the English Language Arts Network and she gives poetry readings in and around the city. 